Diabetologia 8, 111-116 (1972)

(C) by Springer-Verlag 1972

\title{
The Mechanism of Insulin Secretion after Oral Glucose Administration
}

\section{Reflex Insulin Secretion in Conscious Dogs Bearing Fistulas of the Digestive Tract by Sham-Feeding of Glucose or Tap Water}

\author{
H. Hommer, U. Frscher, K. Retzlaft, and H. Kröflen \\ Zentralinstitut für Diabetes "Gerhardt Katsch", Bereich experimentelle Diabetesforschung, DDR-2201 Karlsburg \\ and Kreiskrankenhaus Wolgast, DDR-222 Wolgast
}

Received: September 20,1971, accepted: December 6, 1971

Summary. After sham-feeding of glucose, conscious trained dogs bearing double-barrelled fistulas of the oesophagus or of the stomach do not show any blood sugar increase. Nevertheless their IRI-levels in the peripheral venous blood increased considerably. This increase consists of two peaks of short duration between the 5th and the 10th as well as the 15th and the 25th min. Such IRI-peaks occured also after sham-feeding of tap water, but to a smaller extent. Their temporal order corresponds to the early IRI-peaks after oral glucose administration in intact animals, but before the blood glucose increase which was observed by us previously. After the application of glucose into the oral opening of the oesophageal fistula the first IRI-peak does not occur, the second and the third peaks appeared to the same extent. A feed-forward of insulin secretion induced by oral ingestion is suggested. It may be interpreted within the scope of the "entero-insular axis" of the mechanism of insulin secretion.

Le mécanisme de l'insulino-sécrétion après administration orale de glucose. II. Libération réflexe de l'insuline chez le chien éveillé portant des fistules du tractus digestif par alimentation simulée de glucose ou d'eau

Résumé. Des chiens éveillés et entraînés portant des fistules de l'oesophage ou de l'estomac ne présentent aucune élévation du sucre sanguin après alimentation simulée de glucose, néanmoins une augmentation considérable de la concentration insulinique dans le sang veineux périphérique apparaît. Celle-ci consiste en deux pics brefs entre la 5 e et la 10 e min et aussi entre la 15 e et la $250 \mathrm{~min}$. Ces deux pics apparaissent aussi après alimentation simulée d'eau potable, mais à un moindre degré. Leur ordre chronologique correspond aux pics précoces d'IRI que nous avons observés antérieurement, après administration orale de glucose chez des animaux intacts, avant l'élévation glycémique réelle. Après application de glucose dans l'ouverture aborale de la fistule chez des animaux portant une fistule de l'oesophage, il manque le premier pic d'TRI, le deuxième et le troisième pic (provoqués par résorption) apparaissent invariablement. Une insulino-sécrétion intensifiée, couplée à la prise de nourriture et induite par l'ingestion orale est suggérée et discutée dans le cadre de l'sentero-insular axis» du mécanisme de l'insulino-sécrétion.

Der Mechanismus der Insulinsekretion nach oraler Glucosegabe II. Reflektorische Insulinfreisetzung beim wachen Hund mit Fisteln des Magen-Darm-Traktes durch Scheinfütterung mit Glucose oder Wasser.

Zusammenfassung. Wache trainierte Hunde mit doppelläufigen Fisteln des Oesophagus oder des Magens zeigen nach Scheinfütterung mit Glucose keinen Blutzuckeranstieg, aber eine sichere Erhöhung des immunchemisch gemessenen Seruminsulins im peripheren Venenblut. Es wurden zwei kurzzeitige Peaks zwischen der 5. und 10. sowie der 15. und 25. min beobachtet. In geringerem Ausmaß fanden sich diese beiden Peaks auch nach Scheinfütterung mit Leitungswasser. Sie entsprechen in ihrer zeitlichen Anordnung den von uns früher beobachteten frühen Insulingipfeln nach oraler Glucosegabe an intakte Tiere vor dem eigentlichen Blutzuckeranstieg. Bei Glucoseverabfolgung in die aborale Fistelöffnung von Oesophagusfistelträgern fehlt der erste IRI-Gipfel, der zweite und der dritte (resorptionsbedingte) sind unverändert ausgeprägt. Fs wird eine von Rezeptoren der Mundhöhle ausgelöste Vorwärtskopplung der Insulinsekretion bei oraler Verabfolgung stimulierender Substanzen angenommen und im Rahmen der ,enteroinsulinären Achse" des Insulininkretionsmechanismus diskutiert.

Key words: Oral glucose tolerance, insulin secretion, reflex, sham-feeding, enterohormones.

\section{Introduction}

Food intake and enteral resorption are the most common stimuli for the insulin producing and releasing system. Furthermore we know that enterohormones and the vegetative nervous system participate in insulin mobilization after intake of food (Porte and Bagdade, 1970). This explains why during the oral glucose tolerance test (oGTT) comparatively more insulin is liberated than after intravenous administration (Rehfeld et al., 1970; Elrick et al., 1964). For the first time we could demonstrate this phenome- non in dogs and proved that the insulin secretion during oGTT occured in several phases (Fischer et al., 1972). At least the first phase beginning within a few minutes does not depend upon the subsequent increase of blood glucose. The first phase can also be observed after the administration of tap water alone without any alteration of glycemia.

In further experiments we had to examine what other conditions unaccompanied by a rise of blood glucose (and presumably without an increase of other substances influencing insulin secretion) can induce the mobilization of insulin. For a long time we have known 
that the activity of the exocrine digestive glands may be stimulated by sham-feeding (Pawlow, 1898); therefore it was logical to use these tests for investigating these endocrinological questions. We submitted conscious dogs to sham-feedings of glucose and water and investigated the immunoreactive insulin (IRI) in the peripheral venous blood.

\section{Material and methods}

Animals: Trained pure-bred Alsatian dogs of both sexes ( 7 males and 3 bitches) were used. They had a body weight of $22.4 \pm 0.8 \mathrm{~kg}$ and an average age of $31.6 \pm 2.6$ month. They were starved for $17.3 \pm 0.3 \mathrm{~h}$. The conditions of the experiments and training patterns were described by Fischer et al. (1972). The animals were trained for at least 6 weeks before the first test.

Operation: Under $\mathrm{N}_{2} \mathrm{O} / \mathrm{O}_{2}$-intubation anaesthesia after premedication with Combelen ${ }^{\circledR}$ "Bayer" (N(3'-dimethyl-aminopropyl)-3-propronyl-phenothiazin), starting with i.v. Hexobarbital-Na and relaxation with Myorelaxin ${ }^{\circledR}$ "Arzneimittelwerk Dresden" (Succinylcholinbromide), the dogs were operated on, and double-barrelled fistulas were made in the stomach or oesophagus. Such fistulas allowed the recovery of the whole test solution at the distal opening $2-3$ min after oral administration. Furthermore it is possible to give the test solution as well as the meals in to the aboral opening.

Stomach fistulas: Cutting the abdominal wall in the mid-line, dissecting stomach and duodenum near the pylorus for about $4-6 \mathrm{~cm}$, cutting the stomach at the pylorus with 2 intestinal forceps, styptic sutures, suturing the gastric stump to the left and the pyloric stump to the right side of the abdomen at a distance of $6-8 \mathrm{~cm}$. Then both openings were connected by means of a plastic tube, which was removed during the tests. The tests were performed $5-12$ days post operatively after wound healing. The recovery rate of the administered glucose amounted to $93.1 \pm 1.6 \%$.

Oesophageal fistulas: Cutting over the M. sternocephalicus sin., dissection of the oesophagus for about $4 \mathrm{~cm}$ with careful avoidance of the vessels and nerves which were displaced ventromedially, cutting the oesophagus at the region of larynx, styptic sutures and exposition of both ends in the neck skin with a distance of $4-6 \mathrm{~cm}$ between the openings, bridging the openings by a plastic tube which was removed during the test periods. In this group the tests were carried out 2-16 weeks after the operations, and the recovery rate of the administered glucose amounted to $95.2 \pm 1.3 \%$.

Nutrition of the operated animals: The plastic tubes bridging the fistulas did not allow the passage of foodstuffs in all cases. Frequently they could not be fixed. Therefore artificial feeding through the aboral opening of the fistulas became necessary. The animals were given 3-5 meals a day (mashed meat $2 / 3$, bread or rice or potatoes $1 / 3$, water or small amounts of milk).
Quantity and number of meals were adapted to the body weight and liquid balance. Depending on the individual circumstances this regime started about 2 days after operations. Up to that time the balance was maintained by means of s.c. and i.v. infusions. The dogs with oesophageal fistulas could be kept for a long time. The dogs bearing stomach fistulas, however, recovered only partially despite substitution therapy with hydrochloric acid and enzymes. Therefore they had to be withdrawn from the program after 2 weeks.

Tests: Whithout premedication the conscious dogs were tested at 7.30 a.m. after starvation period of $17.6 \pm 0.3 \mathrm{~h}$. They were given $1.0 \mathrm{~g}$ glucose per $\mathrm{kg}$ body weight in $50.0 \mathrm{ml}$ tap water $\left(37^{\circ} \mathrm{C}\right)$ orally or in some cases into the aboral opening of the oesophageal fistulas. The administered solution was recovered at the oral end of the fistula. If glucose was given the sugar was estimated in the recovered liquid. In a further series of 9 experiments the dogs with oesophageal fistulas received $50.0 \mathrm{ml}$ tap water by mouth. In a preceding paper we described the test conditions, the method of administration and the pattern for getting blood specimens from the peripheral veins (Fischer $e t$ al. 1972).

Analyses: We measured the concentration of blood glucose (Köhler, 1962), free fatty acids (FFA) (Duncombe, 1964) and IRI (Ziegler et al., 1969) ${ }^{1}$ in the peripheral venous blood by means of a backtitration principle with alcoholic precipitation.

Calculations: The mean \pm SEM $\left(\overline{\mathrm{x}} \pm \mathrm{s}_{\overline{\mathrm{x}}}\right)$ of the measured values are given. The differences were determined by the $t$-test $(p<0.01)$. For all measured parameters the peak areas of the curves were ascertained as the sum of the following products (time interval with regard to the single value) - (individual value minus the starting value).

We assumed that two adjacent values were linearly connected. Moreover, we analysed each single curve with regard to the appearance of several peaks. Each peak was verified by at least 2 adjacent points and demonstrated by a concentration value (maximum value minus starting value) and a time value (distance to the end of application). The last finding need not be identical with a defined point of a blood specimen, because the individual animals produced different responses and we calculated the means ${ }^{2}$.

\section{Results}

In dogs bearing stomach fistulas the oral application of glucose with subsequent recovery of the test solution was not accompanied by a reliable increase of blood glucose. (Fig. 1, Table 1). The single values do not differ from one another, and the net area is not different from zero. Nevertheless a rise is seen in IRI

1 We are grateful to Dipl.-Chem. M. Ziegler for measuring the insulin concentrations.

$2 W_{e}$ are grateful also to Dipl.-Math. E. Jutzi for calculating the statistical figures. 
which seems to be multiphasic or irregular. Only the $20 \mathrm{~min}$ value differs significantely from the $0 \mathrm{~min}$ value. But the net area, in general reveals a definite elevation.

Table 1 demonstrates that in a few dogs this IRIincrease comprises 2 separate peaks and that these peaks correspond to those after oral glucose application in normal dogs preceding the increase of blood glucose Indeed the IRI-area is smaller than after an oGTT in intact animals but the difference was not significant. gastric mucosa is essential for the observed phenomenon. Therefore we repeated such sham-feedings in bearers of oesophageal fistulas (Fig. 2, Table 1). In these cases a rise of blood glucose was not to be seen. Nevertheless, there was a distinct IRI-increase which occurred at $2.5,5.0$ and $7.5 \mathrm{~min}$, and the net area could be proved statistically. In all cases the evaluation of the individual curves showed two distinct peaks, as represented in Table 1 . They occur before the insulin rise which can be expected in intact dogs after

Table 1. Time values and concentration differences of the IRI and glycemic maxima and net areas of IRI, glycemia and FFA $(0-90 \mathrm{~min})$ in the various tests reported in this paper also after oral application of $1.0 \mathrm{~g}$ glucose per $\mathrm{kg}$ in intact dogs (data from Table 1, Fischer et al., 1972)

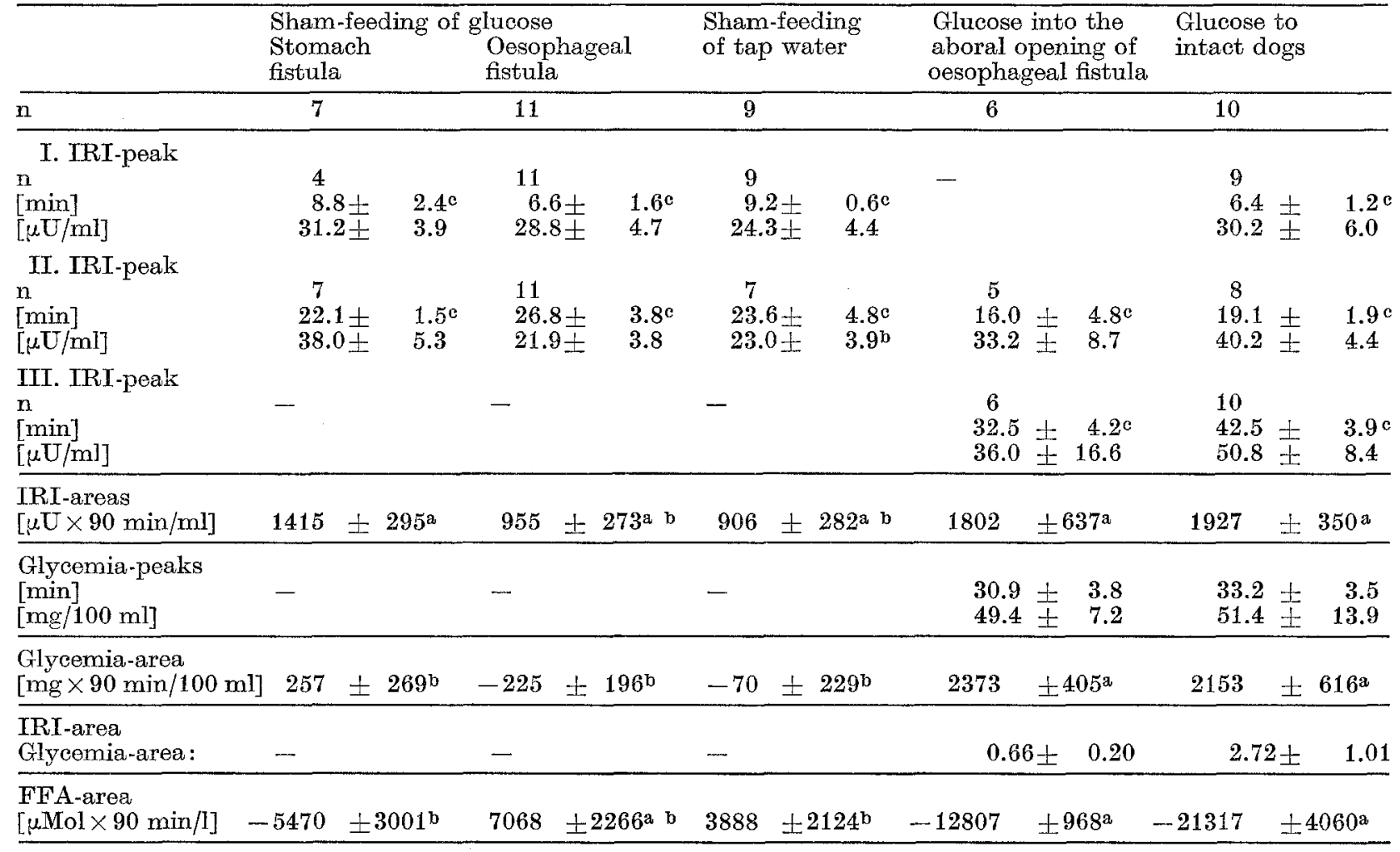

Statistical analysis

$\mathrm{a}=p<1 \%$ with regard to zero

$\mathrm{b}=p<1 \%$ for the differences to glucose administration in intact animals

$\mathrm{c}=p<1 \%$ for the differences between two adjacent IRI-peaks

Glucose is only a weak stimulus for insulin secretion in the carnivorous dog, and further physiologic factors must be of importance.

Despite considerable insulin release the FFA decrease was not significant. But it must be taken into consideration that we have demonstrated a rise in FFA of long duration without increase of insulin in the only possible comparable control situation, the i.v. application of $0.9 \% \mathrm{NaCl}$ (Fischer et al., 1972). Therefore these findings can be considered in agreement with the measured alteration of IRI. Now the question arises whether the direct contact of the test solution with the oral administration. The apparent additional peak at $40 \mathrm{~min}$ could not be proved statistically. The FFA increased, but this rise was interrupted between the 10 th and 30 th $\mathrm{min}$.

These results suggest the mobilization of insulin on the basis of nervous reflexes. In intact animals we could demonstrate this phenomenon by giving tap water orally. The specificy was investigated again by giving water to the animals with oesophageal fistulas. After such sham-feeding of water (Fig. 3, Table 1) a significant IRI-peak appeared at $10 \mathrm{~min}$. The net area was statistically significant, but smaller than in the 


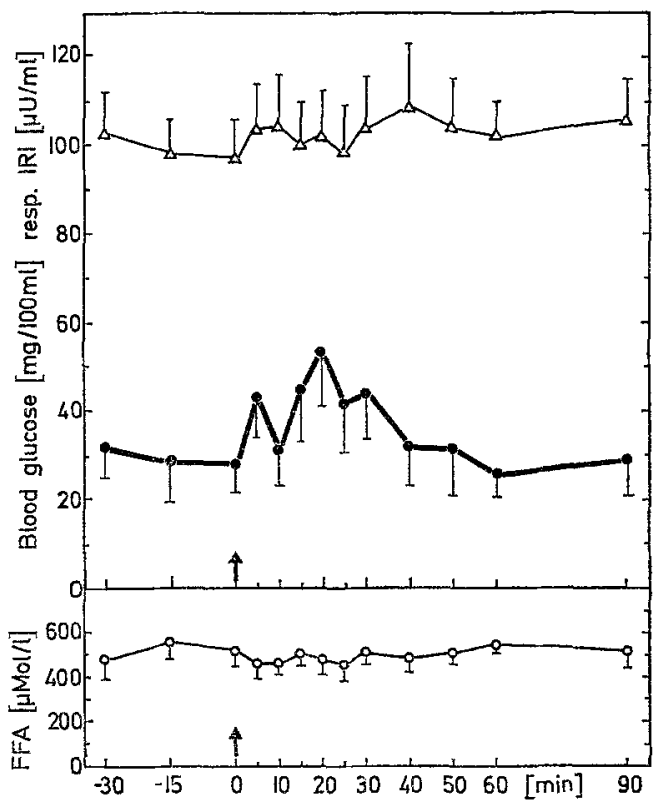

Fig. 1. Blood sugar, IRI and FFA after sham-feeding of $1.0 \mathrm{~g}$ glucose $/ \mathrm{kg}$ in $50.0 \mathrm{ml}$ tap water to dogs with stomach fistulas ( 7 experiments in 4 animals)

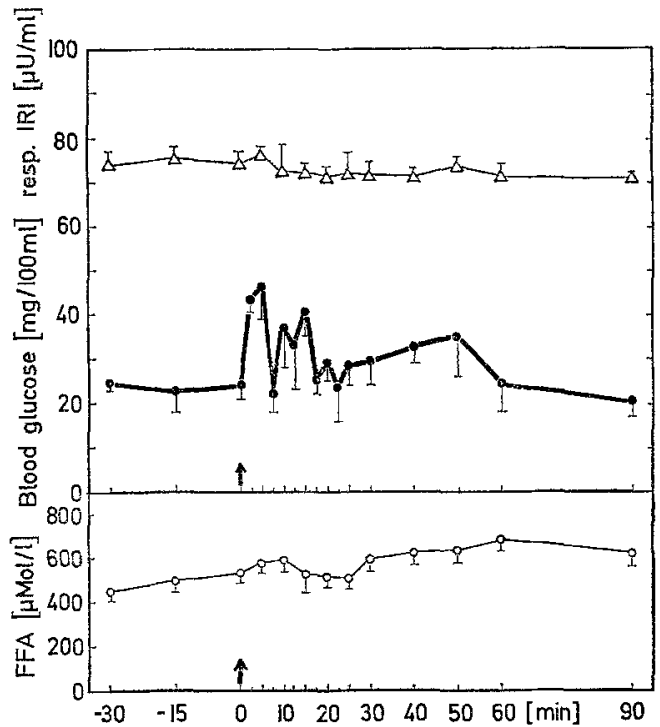

Fig. 2. Blood sugar, IRI and FFA after sham-feeding of $1.0 \mathrm{~g}$ glucose $/ \mathrm{kg}$ in $50.0 \mathrm{ml}$ tap water to dogs with oesophageal fistulas (11 experiments in 6 animals). Symbols as demonstrated in Fig. 1

other tests. There were also two peaks of IRI, in accordance with a temporaray small blood sugar decrease as well as an interruption of the FFA increase.

These findings suggest that insulin is released in a first phase with participation of factors localized in the cavity of the mouth. This kind of insulin secretion should not occur, if glucose is given directly into the aboral opening of the oesophageal fistula, i.e. by-passing the mouth (Fig. 4, Table 1). In principle the course

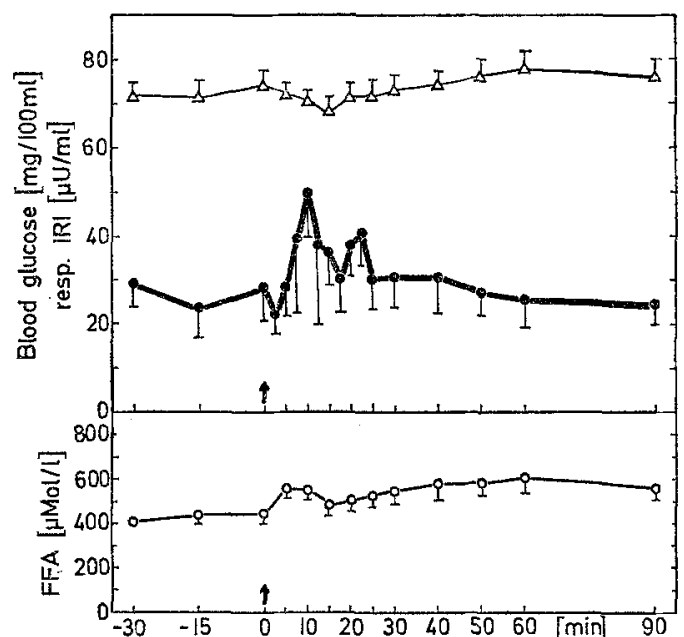

Fig. 3. Blood sugar, IRI and FFA after sham-feeding of $60.0 \mathrm{ml}$ tap water to dogs with oesophageal fistulas (9 experiments in 5 animals). Symbols as demonstrated in Fig. 1

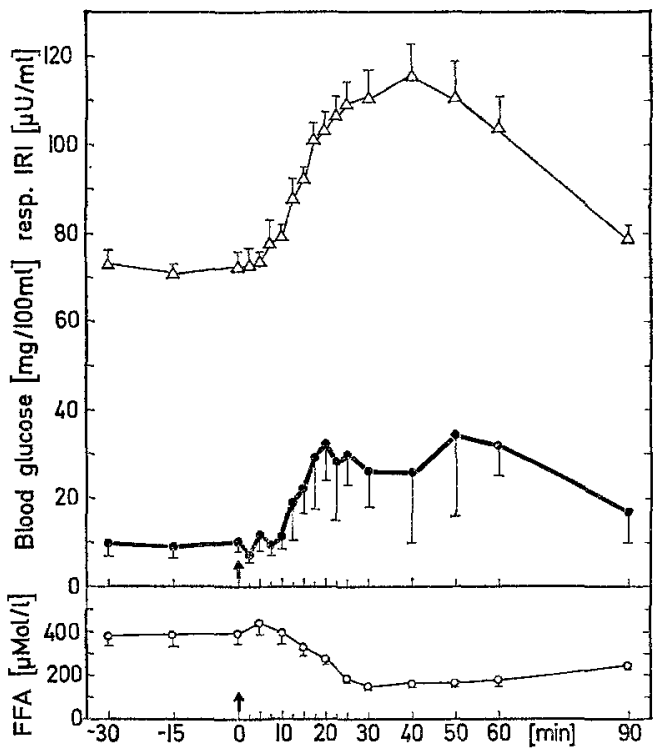

Fig. 4. Blood sugar, IRI and FFA after application of $1.0 \mathrm{~g}$ glucose $/ \mathrm{kg}$ in $50.0 \mathrm{ml}$ tap water into the aboral opening of tho oesophageal fistula to dogs with oesophageal fistulas (6 experiments in 4 animals). Symbols as demonstrated in Fig. 1

of glycemia does not differ from that after oral glucose application in intact dogs. The IRI-values, however, increase only after the $10 \mathrm{th} \mathrm{min}$. This fact is confirmed by an analysis of the peaks. Experiments did not reveal such a peak before $12.5 \mathrm{~min}$, and the first peak reached here corresponds to the second rise of all other tests. It was seen in 5 animals. The second peak of these experiments corresponds to the increase of blood sugar due to enteral resorption. An index of the 
liberated insulin per unit of time in relation to the unit of blood sugar increase is represented by the ratio between the IRI- and glycemia-areas. We could already demonstrate that it is smaller after i.v. glucose administration than after oral administration (Fischer et al., 1972). In the current experiments this ratio is essentially diminished by by-passing the mouth, i.e. a definitely smaller amount of insulin is liberated in relation to the rise of glycemia.

The course of the FFA does not significantly differ from that after oral application in intact animals. We may conclude that in avoiding the oral cavity some parts of the mechanisms inducing a forward-coupling of the insulin secretion do not occur at all or they start markedly later.

\section{Discussion}

Our previous findings indicated that in most cases after oral glucose application in conscious dogs two short phases of insulin mobilization not connected with resorption of glucose precede the IRI-peak produced by the rise of blood sugar. Both phases were demonstrable in the same time pattern in situations where the resorption of sugar after glucose administration was prevented by fistulas as well as after administration of water in intact dogs or animals with fistulas (Fischer et $\alpha l$., in press). With exception of the stomach fistula experiments, the IRI-peak values and net areas were smaller in comparison with intact dogs.

The assumption of a forward-coupled and intensified secretion of insulin after oral stimulation seems to be justified despite the individually different reactions. Such an intensifying effect was proposed by Unger, 1970 and Unger et al., 1967, in consequence of the manifold effects of the enterohormones. With respect to the influence of these enterohormones (Kahil et al., 1970; Dupré, 1970; Kraegen et al., 1970; White and Dupré, 1968; Rehfeld et al., 1971) and of the vegetative nervous system (nervus vagus: Daniel and Henderson, 1967; Frohman, 1967; adrenergic system: Mariani et al., 1967; Majid et al., 1970; Cerasi et al., 1969 , Porte, 1969) the function of an "entero-insular axis" was proposed. Similar results were hitherto found only by Rehfeld (1970): in patients with an enteroanastomosis the resorption of glucose is diminished or absent. Nevertheless an increase of insulin concentration in the peripheral venous blood was shown after oral glucose loadings in such persons.

The physiological importance of such reinforcing mechanisms is as yet, unsatisfactorily investigated. Phenomenologically insulin is a regulating unit in a control system which keeps the blood glucose supply constant for the peripheral tissues and enables the utilization of all important substrates (Mohnike, 1961). Considering that the food intake is an important and daily repeating stimulus for insulin release we may assume a coupling of the secretion of insulin with other food reflexes (Pawlow, 1898). In the carnivorous dog where glycemia is obviously not a strong insulinogenic stimulus such mechanisms may be investigated especially well. Their quantitative importance must not be neglected, as shown by results in animals with stomach fistulas.

The evaluation of the two early peaks, (Table 1) allows some assumptions about the mechanisms involved. Within the first $10 \mathrm{~min}$ a separate phase of IRI-increase is observed, in which glycemia is unchang. ed. This first phase appears only after the administered solution comes into contact with the oral cavity and it is quantitatively equal in all situations investigated. The kind of the afferent and the efferent mechanisms involved can not be evaluated.

But it is interesting that the insulin release after electrical stimulation of the nervus vagus requires a similar short time (Frohman et al., 1967). Moreover we know that gastrin (Grossman, 1970; Pethein and Schoffield, 1959) and secretin (Gregory, 1962; Ribet and Pascal, 1968) may be released by means of reflexes or direct vagal stimulation. Finally, the rise of secretin after oral stimulation also occurs during the first $5 \mathrm{~min}$ (Chisholm et al., 1969). For this first phase a purely nervous or a nervous-hormonal mechanism may be involved.

The second phase already coincides with the early increase of blood sugar. Its pattern and extent vary considerably depending on the test chosen. In the experiments without any rise of blood sugar this 2 nd peak appears most clearly after sham-feeding of glucose to animals with stomach fistulas. This agrees with the release of enterohormones by a directly local stimulation of the stomach mucosa (Grossman, 1962, Grossman et al., 1948, White et al., 1960). With reference to the time pattern, we may compare these findings with the changes of gastrin in the peripheral serum by oral glucose (McGuigan and Trudeau, 1970) or a meal (Walsh et al., 1971).

In the afferent limb certain nervous factors obviously play an important part. In the efferent limb the enterohormones are probably involved. In this connection we have to stress the importance of gastrin and secretin whose stimulating action on insulin secretion is intimately coupled with the exocrine pancreatic function (Hinz et al., 1971; Goberna et al., 1971).

Presumably pancreozymin/cholecystokinin does not play an important role in this early phase since it is not known its release is controlled by the nervous system (Hong et al., 1956, Vagne, 1970, Magee, 1962). Furthermore an increase of this hormone after oral glucose was found in the peripheral venous blood but a direct relationship with insulin secretion does not appear likely (Young et al., 1968, 1969).

Acknowledgements. The authors are grateful to Mrs. Helga Schröder, Mrs. Karla Brüllke, Mrs. Edith Fischer and Mr. Wolfgang Schrötter for careful technical assistance. 


\section{Literatur}

1. Cerasi, E., Effendic, S., Luft, R.: Role of adrenergic receptors in glucose-induced insulin secretion in man. Lancet 1969 II, $301-302$.

2. Chisholm, D.J., Young, J.D., Lazarus, D.: The gastrointestinal stimulus to insulin release. I. J. elin. Invest. 48, 1453-1459 (1969).

3. Daniel, P.M., Henderson, J.R.: The effect of vagal stimulation on plasma insulin and glucose levels in the baboon. J. Physiol. 192, 317-326 (1967).

4. Duncombe, W.G.: The colorimetric micro-determination of nonesterified fatty acids in plasma. Clin. chim. Acta 9, 122-125 (1964).

5. Dupré, J.: Regulation of the secretions of the pancreas. Ann. Rev. Med. 21, 299-316 (1970).

6. Elrick, H., Stimmler, L., Hlad jr., C.H., Arai, Y.: Plasma insulin response to oral and intravenous glucose administration. J. clin. Endocr. 24, 1076-1082 (1964).

7. Fischer, U., Hommel, H.: Experientia 27, 397 (1971). Insulinmobilisierung beim Hund durch Scheinfütterung mit Glukose.

8. - - Ziegler, M., Michael, R.: The mechanism of insulin secretion after oral glucose administration $\mathrm{I}$. Multiphasic course of insulin mobilization after oral administration of glucose in conscious dogs. Differences to the behaviour after intravenous administration. Diabetologia 8, 104-110 (1972).

9. Frohman, L.A., Ezdinli, E.Z., Javid, R.: Effect of vagotomy and vagal stimulation on insulin secretion. Diabetes 16, 443-448 (1967).

10. Goberna, R., Fussgänger, R.D., Raptis, S., Telib, M., Pfeiffer, E.F.: The role of the exocrine pancreas in the stimulation of insulin secretion by intestinal hormones. II. Insulin responses to secretin and pancreozymin in experimentelly-induced pancreatic exocrine insufficiency. Diabetologia 7, 68-72 (1971).

11. Gregory, R.A.: Secretory mechanism of the gastrointestinal tract, p. 135. London: E. Arnold. Publ. Ltd. 1962.

12. Grossman, M.I. : Secretion of acid and pepsin response to distension of vagally innervated fundic gland area in dogs. Gastroenterology 42,718 - 721 (1962).

13. - Gastrin and its activities. Nature 228, 1147-1150 $(1970)$

14. - Robertson, C.R., Ivy, A.C.: The proof of a hormonal mechanism for gastric secretion. The humoral transmission of the distension stimulus. Amer. J. Physiol. 153, 1-9 (1948).

15. Hinz, M., Katsilambros, N., Schweitzer, B., Raptis, S., Pfeiffer, E.F.: The role of exocrine pancreas in the stimulation of insulin secretion by intestinal hormones I. The effect of pancreozymin, secretin, gastrinpentapeptide and of glucagon upon secretion of isolated islets of rat pancreas. Diabetologia 7, 1-5 (1971).

16. Hong, S.S., Magee, D.F., Crewdson, F.: The physiological regulation of gallbladder evacuation. Gastroenterology 30,620-630 (1956).

17. Kahil, M.E., MeIlhany, G.R., Jordan, P.H.: Effect of enteric hormones on insulin secretion. Metabolism $19,50-57(1970)$

18. Kraegen, E.W., Chisholm, D.J., Young, J.D., Lazarus, L.: The gastrointestinal stimulus to insulin release. II. A dual of secretion. J. clin. Invest. 49, $524-529(1970)$.

19. Köhler, P.: Verbesserte Glucoseoxydasemethode zur Blutzuckerbestimmung im Routinebetrieb des klinischen Laboratoriums. Z. ges. inn. Med. 17, 674-676 (1962).

20. Magee, D.F.: Gastrointestinal physiology. Springfield: Thomas 1962.
21. Majid, P.A., Saxton, C., Dykes, J.R.W., Galvin, M.C., Taylor, S.H.: Automatic control of insulin secretion and the treatment of heart failure. Brit. med. J. 1970 IV, $328-334$.

22. Mariani, M.M., Chapel, J., Loubatières, A.: Isoprénaline propanolol, et insulino-sécrétion. Etude sur le pancréas isolé et perfusé du rat. C. r. Soc. Biol. 168, $2390-2395(1969)$.

23. MeGuigan, J.E., Trudeau, W.L.: Studies with antibodies to gastrin. Radioimmunoassay in human serum and physiological studies. Gastroenterology 58, 139$150(1970)$.

24. Mohnike, G.: Pharmakologie der Blutzuckerregulation. Körpereigene Stoffe. Naunyn-Schmiedebergs Arch. Pharmak. 241, 6-34 (1961).

25. Pawlow, J.P.: Die Arbeit der Verdauungsdrüsen. Wiesbaden: J.F. Bergmann-Verlag 1898

26. Pethein, J., Schoffield, B.: Release of gastrin from the pyloric antrum following vagal stimulation by shamfeeding in dogs. J. Physiol. (Lond.) 148, 291-305 (1959).

27. Porte, D., jr.: Sympathetic regulation of insulin secretion. Arch. int. Med. 123, 252-270 (1969).

28. - Bagdade, J.D.: Human insulin secretion : an integrated approach. Ann. Rev. Med. 21, 219-240 (1970).

29. Rehfeld, J.E.: Effect of gastrin and its C-terminal tetrapeptide on insulin secretion in man. Acta endocr. $66,169-1.76(1971)$

30. - Hippe, E.: Serum insulin response to oral glucose in pernicious anemia. Scand. J. Gastroenterol. 5, 713-718 (1970).

31. - Juhl, F., Quaade, F.: The intestinal insulinotropic action after jejuno-iliostomy. Scand. J. Gastroenterol. 5, 77-80 (1970).

32. Ribet, A., Pascal, J.P.: Le pancréas exocrine. Paris: Masson 1968.

33. Unger, R.H.: Possible role of insulin-stimulating hormones in disturbances of nutrient tolerance. Adv. metab. Disord., Suppl. 1, 125-131 (1970).

34. - Ketterer, H., Dupré, J., Eisentraut, A.M.: The effects of secretin, pancreozymin, and gastrin on insulin and glucagon in anaesthetized dogs. J. clin. Invest. 46, 630-645 (1967).

35. - Ohneda, A., Aguilar-Parada, E., Eisentraut, A.M. The role of aminogenic glucagon secretion in blood glucose homoeostasis. J. clin. Invest. 48, 810-822 (1969).

36. Vagne, M.: Gastrointestinal hormones. II. Cholecystokininpancreozymin. Path. Biol. 18, 997-1012 (1970).

37. Walsh, J.H., Yalow, R.S., Berson, S.M.: The effect of atropine on plasma gastrin response to feeding. Gastroenterology 60, 16-21 (1971).

38. White, T.T., Lundh, G., Magee, D.F.: Evidence for the existence of gastropancreatic reflex. Amer. J. Physiol. 198, 725-728 (1960).

39. White, J.J., Dupré, J.: Regulation of insulin secretion by the intestinal hormone secretin in man via transumbilical portal vein catheterization. Surgery 64, $204-213(1968)$

40. Young, J.D., Lazarus, L., Chisholm, D.J.: Secretin and pancreozymin-cholecystokinin after glucose. Lancet 1968 II, 914-916.

41. - - - Atkinson, F.F.V.: Radioimmunoassay of pancreozymin-cholecystokinin in human serum. $\mathrm{J}$. nucl. Med. 10, 743-748 (1969).

Dr. H. Hommel,

Zentralinstitut für Diabetes

"Gerhard Katseh",

Bereich experimentelle Diabetes-

forschung,

DDR-2201. Karlsburg 